\title{
Management Control Systems, Organizational Culture and Village Credit Institution Financial Performance
}

\author{
I MADE PRADANA ADIPUTRA* \\ EDY SUJANA \\ Ganesha University of Education
}

\begin{abstract}
This study aims to provide empirical evidence about the influence of misfit management control systems (levers of control) with an organizational culture that will negatively affect the financial performance of Village Credit Institution (LPD). This study uses a survey method (questionnaire) based on a sample of 149 LPD units in Buleleng Regency with purposive sampling criteria. The research respondents were all three LPD officers (penyarik, pemucuk, and petengen) and one staff each from the credit and accounting department. The research hypothesis suggests that each organizational culture orientation, namely clan, adhocracy, hierarchy, and market, shows a fit (through misfit values) with levers of control (belief, boundary, diagnostic, and interactive control system) has a negative effect on LPD financial performance. The analysis technique uses OLS regression residual approach to testing the research hypothesis. The results showed that the hierarchical culture was able to have a fit (a small misfit value) with a management control system (levers of control) to influence the financial performance of the LPD.
\end{abstract}

Keywords: Management Control System, Organizational Culture, LPD Financial Performance

\begin{abstract}
Abstrak - Penelitian ini bertujuan untuk memberikan bukti empiris tentang pengaruh sistem pengendalian manajemen misfit (levers of control) dengan budaya organisasi akan berpengaruh negatif terhadap kinerja keuangan LPD. Penelitian ini menggunakan metode survei (kuesioner) berdasarkan sampel 149 unit LPD di Kabupaten Buleleng dengan kriteria purposive sampling. Responden penelitian adalah ketiga petugas LPD (penyarik, pemucuk dan petengen) dan masing-masing satu staf dari bagian kredit dan akuntansi. Hipotesis penelitian menduga bahwa setiap orientasi budaya organisasi yaitu marga, adhokrasi, hierarki dan pasar menunjukkan kesesuaian (melalui nilai misfit) dengan levers of control (belief, boundary, diagnostic dan interactive control system) berpengaruh negatif terhadap kinerja keuangan LPD. Teknik analisis menggunakan pendekatan residual regresi OLS untuk menguji hipotesis penelitian. Hasil penelitian menunjukkan bahwa budaya hierarki mampu memiliki fit (nilai misfit yang kecil) dengan sistem pengendalian manajemen (levers of control) untuk mempengaruhi kinerja keuangan LPD.
\end{abstract}

Kata Kunci: Sistem Pengendalian Manajemen, Budaya Organisasi, Kinerja Keuangan $L P D$

\footnotetext{
* Corresponding author: adiputra@ undiksha.ac.id
} 


\section{Introduction}

The Village Credit Institution (Lembaga Perkreditan Desa (LPD) in Indonesian) is a financial institution established by the Pakraman village to benefit public services, especially in the economic sector, aimed at improving the welfare of the Pakraman village community itself. LPD, as one of the fast-growing Micro Finance Institutions in Bali Province, is at the level of a Traditional Village. Its existence so far has been proven, and the Krama Desa Adat greatly feels its benefits. Krama is a community group residing in a traditional village. LPD is not only beneficial according to its function but also creates jobs (Kurniasari, 2007). The LPD has a significant role in informal sector enterprises. The added value of LPDs makes its customers, especially small and microentrepreneurs, prefer LPDs to formal financial institutions as backup finance in their business. This added value then makes LPDs in Bali superior to existing formal financial institutions (Kurniasari, 2007). The uniqueness of the LPD is that it operates based on Hindu customs and culture. The management system is professionally managed based on a modern banking system and technical operations under the Regional Development Bank supervision (BPD).

The legal basis for the LPD was initiated through the Governor's Decree Number 972 of 1984 concerning the Establishment of Village Credit Institutions in the Province of Bali. This was indicated by the LPD establishment project being carried out simultaneously in all Pakraman villages in Bali. Until now, the legal basis for the LPD in effect is Regional Regulation Number 3 of 2017, which replaces Regional Regulation Number 8 of 2002 to make revisions related to operational rules and LPD administrators so that it is expected to strengthen its identity as a Village-owned financial institution located in the village according to the provisions article 1 point 9.

The existence of LPDs in various areas in Bali is very capable of helping the economy of the surrounding community. This is because the LPD carries out a financial function optimally in managing the financial potential of Pakraman village to improve

the economy of Pakraman village (Trisnawati et al., 2019). Meaning 35 years since its establishment in 1984, LPD has challenges to answer today's challenges. According to 
Nyoman Cendikiawan, as Chairman of the LPD Cooperation Agency, 35 has a significant meaning as motivation. The number three means Tri Kaya Parisuda, which must be done and become a reference in activities in the LPD, namely thinking (manacika), saying (wacika), and doing (kayika) right.

Meanwhile, the number five includes things that are contained in Panca Ma that should be avoided in LPD operations, such as memaling (stealing), memitra (having an affair), memadat (compelling), and memotoh (gambling). However, if the numbers three and five add up, the result is eight, associated with Asta Brata or a leader who must be emulated (Bisnisbali.com). Pancadana \& Parwata (2012) uses the values in the teachings of Catur Purusa Artha, namely the four goals of human life, namely Dharma, Artha, Kama, and Moksa, which are used as the basis for LPD operations. LPD business activities must be based on goodness or dharma, after which it leads to benefits, namely artha with the benefits obtained that will be able to fulfill the wishes or kama of the community so that when the desire or kama has been fulfilled, then moksa is the realization of happiness and prosperity.

The motivation for this research is based on the occurrence of environmental changes to internal policies, especially the existence of an organization. These environmental changes mainly occur because of the uncertainty that requires organizations to strengthen themselves against the individuals in them. Strengthening internal factors in LPDs has become the focus of several studies on the existence and performance of LPDs. (Suryanata, 2019) proves that LPDs are better when they synergize with village leaders and traditional village communities in building the economy of rural communities. According to him, to maintain the LPD's competitive advantage in improving the indigenous village community's economy, the LPD manager must pay attention to internal factors both in terms of organization and personal management of the LPD. Pancadana \& Parwata (2012) revealed that the values of religious law or Hindu religious teachings caused the LPD's performance to increase when the LPD applied the concept of religion in carrying out its activities. Research by Trisnawati et al. (2019) also found that the value of religious values influenced the 
LPD's financial performance in Buleleng Regency as part of the LPD's organizational culture and capital structure.

Based on data for the first, second, and third quarters of 2019, the acquisition of LPD assets and profits according to the LPD health level calculation shows the reality of a non-linear relationship between assets and profits on the health level of the LPD (ekbangsetda.bulelengkab.go.id). Ideally, there should be a linear relationship between the two components. Asset management used to generate LPD profits should have increased significantly according to the Bali Provincial Regulation Number 4 of 2012 concerning the Second Amendment to the Bali Provincial Regulation Concerning Village Credit Institutions Concerning LPD Health Assessment Procedures, which was subsequently updated in Governor Regulation Number 44 of 2017 as the Implementation Regulation of Bali Provincial Regulation Number 3 of 2017 concerning LPD with the methods used are Capital, Asset, Management, Earning, Liquidity (CAMEL). In particular, the LPD management aspect assessment relates to the evaluation of LPD management through structured interviews with LPD leaders or administrators regarding general management and risk management statements. The indication of the LPD health assessment is in the healthy to unhealthy category and even stops operating. Thus it will greatly depend on internal organizational factors in carrying out LPD financial and human resource management. There is an indication that the assessment of LPD management aspects is related to the evaluation of LPD management regarding general management and risk management statements related to the management control system (MCS), which must be explored and identified the problems further to obtain answers to the emergence of several LPD problems to date which lead to individual error factors within the organization. The reality is that the mismanagement factor that occurs is caused by fraudulent acts by individuals as LPD administrators. This action dominated the internal problems of the LPD, resulting in the LPD being unable to continue its operations as a traditional village financial institution and reducing the trust of the indigenous village community, and clarifying the 
identification of the problem. This requires a study of the internal conditions of the organization, which includes values including behavior in the organization.

A framework called a management control system that comprehensively shows the aspects of core values, behavior, monitoring, and feedback. One of the MCS concepts is called the levers of control (LoC) proposed by Simons (1994). LoC frameworks inform and motivate employees to take purposeful action. The role of MCS has an impact on the realization of the effectiveness of organizational control, especially in 4 (four) groups of control, namely beliefs control providing basic values, goals, and direction for the organization, boundary control communicating risks that must be avoided (Bedford, 2015). Diagnostic control monitors organizational results and corrects deviations from performance standards and interactive controls that communicate information between superiors and subordinates (Simons, 2014). The LoC framework has been widely used in research in the field of management control for more than two decades (Martyn et al., 2016). The study results indicate the expansion of the application of the framework for broader organizational issues such as sustainability, environmental accounting, inter-organizational control, understanding of antecedents, and the results of using MCS.

Previous research still uses a basic / core value framework which is part of the belief control system. Pancadana \& Parwata (2012) analyzed and formulated the concept of Catur Purusa Artha as the basis for LPD business activities. The values of Catur Purusa Artha affect the financial performance of the LPD (Trisnawati et al., 2019). (Suryanata, 2019) found that the synergy of the LPD, traditional village officers, and indigenous village communities affects the economic development of indigenous village communities. LPD managers use the teachings of Tri Hita Karana as the basis for LPD governance. These studies still focus on core values / beliefs as one of the levers of control components, namely using local content measurements, which give results in a limited scope. Meanwhile, each organization also builds its organizational culture to form organizational values that cannot be separated from professional operational 
activities. This should be integrated with LoC but has not yet become an essential issue in the research.

Research by Suartana \& Ariyanto (2012) and Agustina et al. (2017) proved that LPD financial information could impact LPD operations. However, this study did not analyze the organization's value factors, which play a major role in determining LPD performance. This research examines the existence of the LPD as seen from the organization's professional operational activities according to financial ratios and regulations related to LPD performance appraisal. However, this research has shown that the role of individual LPDs also determines whether the LPDs perform well. The MCS research through levers of control was carried out in small and medium enterprises in the Netherlands by Pešalj et al. (2018). The results of his research show that SME managerial practice allows the interaction of four components of levers of control, namely: belief, boundary, diagnostic and interactive, helping organizations manage organizational tensions related to short and long term focus, achieving predictable goals, and looking for new opportunities, focus, internal and external control and creativity of SMEs.

Based on this description, this research was conducted to fill the previous research gap on LPD performance based on internal organizational factors in a more comprehensive manner through the implementation of MCS, including belief, boundary, a diagnostic and interactive control system in non-bank financial institutions, namely LPD. The use of LPD subjects in this study will become a new reference for managing village financial institutions based on customs and culture as novelty research that has not been carried out in previous studies related to MCS. This is mainly based on the uniqueness of the Hindu culture-based microfinance institution that has been previously described. Many cases related to the occurrence of internal conflicts of LPD management are also factors in why a study of values, limits, performance, and interactions at LoC is necessary. The implementation of the MCS is very dependent on the individual who must have conformity with organizational goals. Organizational culture is reflected in the vision and mission, employee attitudes and behavior, and how 
the organization works (Gochhayat et al., 2017). Chenhall (2003) posits that culture is related to MCS design. Even though the cultural context referred to by Chenhall (2003) is a national culture that represents the cultural characteristics of a country, the basic proposition that different countries have specific cultural characteristics and affect individuals who are within that cultural scope will determine the MCS design specifically. Gochhayat et al. (2017) and Zhao et al. (2018) state that organizational culture motivates employees to work towards company goals and can increase its effectiveness, value, and performance.

The relationship between MCS and organizational culture factors is a contingent relationship within the MCS research framework and its contextual factors (Chenhall, 2003; Widener, 2007). Contingent factors or contingent factors, in this case, are factors that affect MCS design in organizations that are contingent or uncertain or absolute for each MCS design. Therefore, the relationship between MCS and organizational culture based on the contingency approach is carried out by analyzing the contingency-fit factor, which will impact organizational performance. This study uses this approach to analyze the fit of the MCS with organizational culture and its effect on the LPD's financial performance.

This study uses the misfit approach used by Gani \& Jermias (2012) to test MCS and business strategy affect bank performance in Indonesia and Adiputra et al. (2019) to test levers of control perceived business uncertainty on hotel performance. Misfit shows that the deviation between management control system variables and strategy has negative implications for performance (Gani \& Jermias, 2012). The misfit concept assumes that the amount of misfit is through the residual concept (Riyanto, 2001). The implementation of the misfit concept is the mismatch of the organizational culture. The higher (lower) the MCS (levers of control) will cause the company's performance to be lower (high). Based on this, the purpose of this study is to provide empirical evidence that the influence of the MCS (levers of control) misfit with organizational culture will have a negative effect on LPD financial performance. 


\section{Theoretical Framework and Hypothesis Development}

\subsection{Contingency theory}

The contingency theory perspective first introduced by Otley (1980) was used in many studies on management accounting and organizational control (Otley, 2016). Furthermore, contingency theory is expanded in scope to include aspects of the MCS used in conjunction with management accounting information and not only focus on management accounting techniques. The idea of a contingency theory will require further clarification because it can be said that all research on these topics has a possible approach that universal solutions to problems in organizational control generally do not exist (Otley, 2016).

A contingency approach is an approach that is often used in management accounting research that bases on the premise that there is no universally applicable accounting system and is applied to all organizations in all conditions (Otley, 1980). Therefore, an exact model of an accounting system depends on the conditions of the organization itself. The development of the accounting system has resulted in developments in the contingency approach. The contingency theory's main proposition is that the contingency theory assessing the performance of the company will depend on the fit between the contextual factors of an organization (Cadez \& Guilding, 2008).

The contingency approach's basic essence also says that organizations must adapt to their contingent factors such as environment, organizational size, and business strategy if the organization is well run (Gerdin \& Greve, 2008). Chenhall (2003) then conducted a meta-analysis of various studies conducted and found that contextual factors are very influential in designing a management control system. These factors are the environment, technology, organizational structure, organizational size, strategy, and organizational culture. These factors are known as organizational contextual variables, which are based on a contingency approach. These factors can also affect organizational performance. Duncan \& Moores (1989) state that organizational effectiveness is a function of the suitability of the organizational structure and the organization's environment. Otley (1980) asserts that organizations adapt to face contingent conditions 
by controlling factors that can be controlled (owned by the company) in order to form an appropriate configuration (fit) so that it is expected to produce organizational effectiveness. A better fit between the control system and the contingent variable is hypothesized to increase organizational performance (Fisher, 1998). The use of the fit in contingency theory shows the level of suitability between contextual factors and accounting systems such as MCS.

There are three approaches to defining the concept of suitability, namely the selection approach, the interaction approach, and the systems approach, as proposed by Drazin \& Van De Ven (1985). The selection approach, however, does not address the system performance implications. The concept of fit in the selection approach shows the relationship between contextual variables and the system itself. Thus, the main focus of research is to examine the characteristics of organizations that adopt a particular system. In this case, the system is in the form of MCS, which is related to its determinant factors.

Further, the interaction approach defines the concept of fit as a bivariate interaction. The concept of fit in the interaction approach is defined as the interaction of pairs of contextual factors on performance. In this fit approach, the main research agenda is to investigate contextual factors that determine or influence the impact of the system on performance. In this study, several contextual factors can be explained in the form of one or more contingent factors interacting with MCS that impact performance.

The systems approach is a concept of fit defined in terms of internal consistency of several possible, structural, and performance characteristics. The effectiveness of the system is determined by the extent to which contextual factors meet the system's conditional requirements; the more consistent the contextual factor with the system, the more effective the system and vice versa. Adopting this approach has allowed researchers to investigate the impact of contextual factors on the relationship between systems and performance. This study can explain the existence of MCS that has a fit between several contingent factors that have been tested for their suitability. Such as business strategy on company performance which is more widely used in several 
management accounting studies that test the typology of business strategy (defender, prospector, analyzer or differentiation and cost leadership) with MCS on performance (such as Chenhall, 2003; Langfield-Smith, 1997; Gani \& Jermias, 2012).

This study uses a systems approach that uses the concept of fit, which analyzes the MCS and the influence of fit factors of organizational culture contingency with MCS on LPD financial performance with a residual approach through the value of misfit, such as the research of (Gani \& Jermias, 2012).

\subsection{Resource Dependence Theory}

Resource Dependence Theory (RDT) 's fundamental assumption is that dependence on critical and essential resources in influencing organizational action, and organizational decisions and actions can be explained depending on specific situations (Pfeffer \& Salancik, 1978). In the context of MCS, RDT is related to the concept of MCS as an accounting system that obtains and uses resources effectively and efficiently in achieving organizational goals, which in its development not only provides information to assist manager tasks, but there are matters related to planning, monitoring, performance measurement, and mechanisms in an integrative way as strategic and operational control (Langfield-Smith, 1997; Chenhall, 2003). Including the concept of levers of control framework, Simons (1987) states that MCS is a formal procedure and system that uses the information to maintain or change patterns in organizational activities. The system broadly includes formal procedures for such matters as planning, budgeting, environmental analysis, competitor analysis, performance reporting and evaluation, resource allocation, and employee rewards. It is clear that the use of human resources, in this case, the duties and functions of the manager, has a vital role in implementing the MCS so that it runs well to create a harmonious purpose between the company and each individual in it. Likewise, the critical role of information on MCS as an accounting system for strategic and operational control of the company so that the MCS can create harmonious objectives between the company and each individual in it. Simons' LoC framework describes each 
levers providing an understanding of how each lever controls these strategic and operational.

\subsection{Management Control System}

In several studies on MCS, the levers of control framework proposed by Simons has gained a prominent position in contemporary management control thinking (Kruis et al., 2015). The LoC framework (Simons, 1994; Simons, 1995) is a business strategy control achieved by balancing the four control levers' strengths, namely: beliefs control, boundary control, diagnostic control, and interactive control. The strengths of the four levers do not work individually, but rather on how levers work together, complement each other and achieve balance (Simons, 1995). Levers are said to generate positive and negative forces that create dynamic pressures between innovation and strategic reforms that need to be managed to achieve the success of organizational goals.

To manage these positive and negative forces, Simons identified two LoCs defined as positive forces, namely the belief control system and the interactive control system. In comparison, the two LoCs were defined as negative forces, namely the boundary control system and the diagnostic control system. Beliefs control system communicates the company's core values which managers formally carry out to provide basic values, goals, and direction for the organization (Simons, 1995). Therefore, the belief control system is used to deal with uncertainty and organizational change conditions because it contains values and sanctions so that it becomes a guide for organizational members to achieve their goals (Mundy, 2010) by adjusting their behavior to the desired results (Speklé, 2001).

Boundary control systems communicate the risks to be avoided by describing the domains of acceptable activities to organizational participants. In it, there are rules of business conduct for coercive members of the organization. This control also applies to managers who serve as a strategic boundary for finding innovative ideas (Simons, 1995). The diagnostic control system is a formal information system used by managers to monitor actual performance and any deviations from predetermined performance 
standards (Simons, 1995). When the MCS in a diagnostic manner is carried out, the manager identifies achievements and deviations from the target plan (Mundy, 2010).

Meanwhile, an interactive control system is a formal information system used by managers to regularly and personally involve themselves in subordinates' decision activities (Simons, 1995). This is necessary when organizations face strategic uncertainties related to changes in competitive dynamics and internal competencies that must be understood if businesses respond to new strategies and successfully adapt over time (Tuomela, 2005; Bisbe et al., 2007). Interactive shows two-way communication between managers and subordinates at the organizational level to plan and achieve organizational goals (Mundy, 2010).

\subsection{Organizational Culture}

Organizational culture, according to OCAI by Cameron \& Quinn (1999) and Cameron et al. (2006), consists of two types of culture that are internally oriented (clan and hierarchy) and externally oriented (adhocracy and market):

a. Clan (also called a collaboration-oriented culture), a kinship culture that develops a friendly workplace where each person shares like a family.

b. hierarchy (also called control-oriented culture), a formal and structured culture. All forms of work are carried out based on procedures and coordination so that the organization will become more stable, predictive, and efficient through formal rules and policies.

c. adhocracy (also called creation-oriented culture), a culture that prioritizes a dynamic workplace, entrepreneurship, and creativity. Focusing on external issues and values such as flexibility and discretion are preferable to stability and controllability.

d. Market (also called a competition-oriented culture)., A culture that values stability and control more focuses on external relations (markets) rather than internal conditions to compete and productivity.

This study will also use the OCAI measurement because of the following considerations: (1) the measurement of organizational culture variables from the development of research on a culture associated with internal organizational factors 
such as LPD. (2). Measuring culture is not limited to the perceived aspects of individual perceptions (as in the questionnaire) so that it is seen as showing the condition of the organization based on organizational data (secondary) if it is assessed from the cultural context that determines the aspects of control from the side of company management, (3). based on the indicator component of the measurement of organizational culture dimensions, it can be more specifically explained the internal and external factors in the cultural components (clan, hierarchy, adhocracy, and market) contained in organizational conditions that can be applied, such as the LPD. Cultural factors have become very popular in researches that use the objects of organizations in the work environment in Bali, one of which is Tri Hita Karana. The limitations of the Tri Hita Karana culture can only be seen from the measurement of the palemahan, pawongan, and parahyangan components, whose indicators are still very general and not specific to the aspect of organizational culture orientation in practice in the organization.

\subsection{LPD financial performance}

Firm performance is one of the most prominent concepts in organizational research. This is related to the main objective of the organization is to find the determinants of organizational performance (Miller et al., 2013). Some organizations have adopted corporate performance evaluation frameworks due to requests for external reporting on these measures (Kaplan \& Norton, 1996; (Ittner et al., 2003). The increasing emphasis on using a combination of firm performance measures has been widely discussed in the accounting literature such as Subramaniam et al. (2011), Jermias \& Gani (2005), and Gani \& Jermias (2012). Competition has forced companies to implement strategies and management systems to overcome dissatisfaction with traditional short-term perspective financial measurement systems (Said et al., 2003). One of the main motivations behind using organizational performance measurement measures to conceptually correct can align an organization's efforts with its strategic objectives (Kaplan \& Nortom, 1996). 
Standard Operating Procedure for LPD management administration where the assessment of the health level of the LPD uses the factors of Capital, Asset, Earning, Liquidity (CAEL). The ability of these CAEL factors is the basis for determining the effect of LPD profit growth (Sujana et al., 2018). Apart from CAEL, it is no less important to pay attention to non-performing loans (NPLs). This is also very important for the LPD to pay attention to because LPD operations are not much different from a Bank Perkreditan Rakyat (BPR) to not disrupt their business continuity (Sujana et al., 2018).

\subsection{Hypothesis}

In accounting, organizational culture is often overlooked because it is considered a value that is taken for granted without being related to company performance. At the same time, organizational culture is a framework that guides managers to improve their organizations' effectiveness (Cameron et al., 2006). Organizational culture is reflected in the vision, mission, attitudes, behavior of employees, and how the organization works (Gochhayat et al., 2017). Chenhall (2003) and Fauzi et al. (2011) proved that (national) culture plays a role in the running of the management control system, effectively influencing individuals in culture to respond in different ways to the implementation of MCS. Concerning company performance, Zhao et al. (2018) found that corporate culture is only related to the innovations made but has no effect on company value and performance.

Organizational culture or company maps the desire for organizational change based on its orientation, namely Clan, Adhocracy, Market, and Hierarchy (Cameron et al., 2006). Companies will not have that one type of culture. The culture of an organization can be seen from the dominant side of the company. The cultural relationship is determined by factors: strength, congruence, type of culture, and organizational effectiveness (Kimbrough \& Componation, 2015). Some of the uses of OCAI are limited to describing the mapping of each type of culture in a particular organization, namely the conditions that occur as expected; no one has directly tested its tendency to be tested for conformity with MCS so that it has an impact on organizational 
performance. No type of culture is better than other types of culture; it all depends on the dominance of the leadership's behavior towards subordinates in an organization to impact organizational performance. Organizational culture will impact performance through coordination and control over the alignment of company and employee goals. Furthermore, corporate culture has an impact on employee motivation and commitment. Organizational culture as a contingent factor in the scope of management accounting research can cause organizations to increase the effectiveness of MCS (Widener, 2007).

Following the contingency theory, MCS must adapt to contingent factors, namely organizational culture, so that organizations can carry out their activities and strengthen themselves according to their cultural orientation to affect organizational performance. Based on the resource dependence theory, the resources owned by the LPD, namely human resources, become the supporters and implementers of the adopted organizational culture and serve as guidelines for the levers of control to impact LPD performance. In this case, MCS must adapt to contingent factors, namely organizational culture, so that the organization can carry out its activities and strengthen itself according to its cultural orientation to affect organizational performance.

This research was first conducted at customary financial organizations such as the LPD. The fit of the LPD's organizational culture with the MCS through levers of control is indicated to impact the financial aspects, LPD management, customers, and individuals who are in it as the LPD's resources. It is based on an accounting system relying on the effective and efficient use of resources to achieve organizational goals. These resources are useful for supporting LPD goals. If there is a condition that does not support each other (misfit) MCS with the LPD organizational culture, it will impact the LPD's financial performance. Every cultural orientation that each individual feels in a unified work system in the LPD and has a fit with the implementation of MCS is thought to affect the LPD's financial performance.

Based on these descriptions, the research hypothesis can be formulated as follows. H1: The existence of a misfit between organizational culture (Clan) and MCS will negatively affect the LPD's financial performance. 
H2: The existence of a misfit between organizational culture (Adocrachy) and MCS will negatively affect the LPD's financial performance.

H3: The existence of a misfit between organizational culture (Hierarchy) and MCS will negatively affect the LPD's financial performance.

H4: The existence of a misfit between the organizational culture (Market) and MCS will negatively affect the LPD's financial performance.

\section{Research Method}

\subsection{Research Data and Samples}

The population and the sample of this research are the Village Credit Institution (LPD) in Buleleng Regency. Reasons for using an LPD located in one district: (a). for the specification of the characteristics of organizations in the same district; (b). variations in the level of health of the LPDs in Buleleng Regency spread from being healthy, quite healthy, unhealthy, unhealthy, and stuck in the health level assessment during 2019; (c). Buleleng Regency is the farthest area in the northern part of Bali Island or the provincial capital, so it is considered to have obstacles to access to information and communication to coordinate organizational activities with related agencies or parties; (d). The same organizational characteristics (homogeneity) will be associated with the use of MCS (levers of control), which tends to be the same through formal procedures and systems of information on organizational activities (Simons, 1995; Simons, 2000) are also relatively the same. Also, as a preliminary study in the first-time testing of MCS in microfinance institutions such as LPDs, limiting the sample to the scope of one district is to seek the feasibility of initial research for research using a wider area of further research.

The data collection method used a questionnaire. Based on the number of LPDs in Buleleng Regency per 2019, there are 169 units. Sampling was done by purposive sampling, with a non-probability method, namely LPDs that are still operating. Based on this, the sample of this study was 149 units because 20 LPD units were no longer operational. To obtain the expected research results according to the variables used in this study, five respondents were determined for each LPD, namely the LPD 
management following Regional Regulation No. 3 of 2017, especially the organizational structure of the LPD, namely 3 LPD prejuru, consisting of:

a. Pemucuk / Head of LPD;

b. Penyarik / Administration;

c. Petengen / Treasurer.

Furthermore, to obtain additional information, two LPD staff were taken as respondents to complete the LPD core management answers, especially in the section that knows about credit and bookkeeping/accounting, which have an essential and strategic role and related to financial problems and LPD performance. LPD staff who were additional research respondents, namely:

a. Credit Section;

b. Bookkeeping / Accounting Section.

\subsection{Research Model}

The empirical research model is formulated as follows:

a. Organizational Culture $=\alpha 0+\alpha 1 \mathrm{MCS}+\varepsilon$

b. Financial Performance $=\beta 0+\beta 1|\varepsilon|+v$

Information:

$\alpha 0, \beta 0, \beta 3=$ Intercept

$\alpha 1, \beta 1, \beta 4=$ Regression coefficient

$\varepsilon, v=$ error

$\varepsilon=$ is the residual value that shows the amount of misfit, which is then isolated to produce the degree of conformity with the MCS to affect performance.

\subsection{Operational Definition of Research Variables}

a. Management control systems in the framework of levers of control are defined as formal and information-based procedures and routines used by management to maintain or change patterns of organizational activity (Simons, 1995; Simons, 2000). Levers of control include beliefs, boundaries, diagnostic and interactive control systems. LoC in this study was measured using 18 question items adopted from (Bedford 2015), consisting of 4 items each to measure the intensity of using 
beliefs control and boundary control. Meanwhile, 5 question items were used to measure the intensity of diagnostic control and interactive control. The integration or joint use of the four levers of control shows the company's MCS implementation. Measurements using a Likert scale 1-5. The higher the score of all question items indicates the higher the intensity of using the levers of control on the LPD.

b. Organizational culture is defined as the values that guide individuals in carrying out their obligations and behavior. Organizational culture in this study was measured using 16 question items adopted from the Organizational Culture Assessment Instrument adopted from (Cameron \& Quinn, 1999) and (Cameron et al., 2006). Organizational culture is seen based on clan (kinship, loyalty, commitment, and sense of organizational ownership), adhocracy (innovation, risktaking, growth, and a dynamic workplace), hierarchy (adherence to formal regulations, stability, and efficiency), and market (productivity, target achievement). Measurements using a Likert scale 1-5. The higher the score of all question items indicates the more robust organizational culture according to the tendency of each cultural component (clan, adhocracy, hierarchy, and market) that occurs in the LPD.

c. LPD Financial Performance is defined as achieving the objectives set by the LPD on the financial aspects during the last three years. LPD performance in this study was measured using 4 (four) question items adopted and developed from Jermias \& Gani (2004) and (Gani \& Jermias, 2012), which was seen from the measurement of LPD financial performance (Sujana et al., 2018). Likert scale 1-5. The higher the score of all question items indicates the higher the standard of achievement of LPD financial performance. Financial performance is seen based on the increase in Profit Growth (CAEL LPD basis), Asset Growth, Operating Cash Flow, and LPD Operational Cost Control. 


\subsection{Statistical Testing}

\subsubsection{Descriptive statistics}

The descriptive statistical analysis aims to provide an overview of research observations by looking at the minimum value, maximum value, average value (mean), and standard deviation value of each variable used in the research model. From the descriptive statistical analysis, it can be seen the characteristics of the observation data.

\subsubsection{Classic assumption test}

a. Multicollinearity test aims to test whether the regression model found a correlation between independent variables (Ghozali, 2012). Multicollinearity detection calculates the tolerance value and Variance Inflation Factor (VIF). The cut-off value commonly used to indicate multicollinearity is a tolerance value $\leq$ of 0.10 or equal to a VIF value $\geq$ of 10 (Ghozali, 2012).

b. The heteroscedasticity test aims to test whether there is an inequality of variance from the residuals of one observation to another (Ghozali, 2012). Heteroscedasticity testing is presented through a scatter plot to determine whether there is a pattern seen from the data distribution. If the pattern in the image shows no indication of forming a certain pattern, heteroscedasticity will not occur and vice versa.

\subsubsection{Data Quality Test}

Survey research relies heavily on answering questionnaires. Therefore, survey research instruments require testing the quality of the data resulting from evaluating the questions in the questionnaire through reliability and validity tests (Ghozali, 2012).

\subsubsection{Hypothesis test}

Testing the research model with residual regression analysis with a misfit approach with an error rate of 5\% using SPSS analysis.

\section{Results and Discussion}

Before testing the research model with regression analysis, previously tested the classical assumptions of multicollinearity and heterocedasticity. After the multicollinearity test was carried out, the results showed that the model did not contain 
any relationship between the independent variables. The VIF values were all below the value of 10. For heteroscedasticity testing, the results showed that with the Glejser test, it showed that the variance of the residuals for all observations in the regression model did not contain heterocedasticity symptoms. . It can be seen that the significance value of all independent variables is more than 0.05 . So it can be concluded that there is no heteroscedasticity problem in the regression model. The validity test through the homogeneity test of the data by conducting a correlation test between the score of each item and the total score (Pearson Correlation) must show a positive and significant correlation at the level of 0.01 to 0.05 . The reliability test has a Cronbach's alpha of more than 0.70 (Ghozali, 2012).

The data is based on the answers of 437 participating LPD administrators who filled out the questionnaire. Respondent profiles by position include 121 LPD heads, 134 LPD administrators, 98 LPD treasurers, 41 credit officers, and 43 accounting officers. Based on gender, namely men as much as $71.37 \%$ and women as much as $28.63 \%$. This is based on the length of service, namely more than ten years as much as $64.32 .50 \%$ and less than ten years as much as $35.68 \%$.

The descriptive statistics of research data $(n=437)$ are shown in Table 1 . below. Table 1.

Descriptive Statistic

\begin{tabular}{lllll}
\hline Variable & Mean & Maks & Min & SD \\
\hline MCS & 78.71 & 84 & 68 & 6.62 \\
LPD Culture: & & & & \\
Clan & 25.81 & 30 & 22 & 2.27 \\
Adhocracy & 24.90 & 30 & 21 & 2.31 \\
Hierarchy & 25.19 & 30 & 19 & 2.77 \\
Market & 25.71 & 30 & 19 & 2.84 \\
Financial Performance & 23.17 & 20 & 22 & 2.91 \\
\hline Sorce procesed
\end{tabular}

Source: processed data 
Table 1 shows that the respondents show the MCS condition through levers of control at a reasonable level, organizational culture both in the type of clan, adhocracy, hierarchy, and market are all in a strong condition for each type of organizational culture, high financial performance standards of achievement, more participation in research.

Hypothesis testing is carried out in 2 (two) steps. The first step of testing the hypothesis using residual regression analysis to find the value of the misfit of organizational culture with MCS by performing a regression analysis of the effect of MCS on each type of organizational culture. The results of the analysis are shown in table 2 below.

Table 2.

Regression Effects of MCS on Organizational Culture

\begin{tabular}{lllll}
\hline Variable & $\begin{array}{l}\text { Clan } \\
(t \text {-statistic })^{\mathrm{b}}\end{array}$ & Adhocracy & Hierarchy & Market \\
& \multicolumn{5}{l}{} & & \\
\hline MCS & $0.213(1.176)^{\mathrm{a}}$ & $0.445(2.673)^{\mathrm{a}}$ & $0.817\left(7.632^{*}\right)^{\mathrm{a}}$ & $0.311(1.763)^{\mathrm{a}}$ \\
R Square & 0.046 & 0.198 & 0.268 & 0.097 \\
$\mathrm{~N}$ & 437 & 437 & 437 & 437 \\
\hline
\end{tabular}

a Standardized coefficients

b Significant at the 0.05 level

Table 3.

Regression Effects of Misfit MCS-Organizational Culture on Financial Performance

\begin{tabular}{lllll}
\hline Variable & $\begin{array}{l}\text { Clan }) \\
(t \text {-statistic })^{\mathrm{b}}\end{array}$ & Adhocracy & Hierarchy & Market \\
\hline Misfit (AbsRes) & $-0.087(-0.473)^{\mathrm{a}}$ & $0.096(0.518)^{\mathrm{a}}$ & $-0.380\left(-2.213^{*}\right)^{\mathrm{a}}$ & $0.246(1.367)^{\mathrm{a}}$ \\
R Square & & & & \\
$\mathrm{N}$ & 0.008 & 0.009 & 0.145 & 0.060 \\
& 437 & 437 & 437 & 437 \\
\hline
\end{tabular}

a Standardized coefficients

b Significant at the 0.05 level 
The second step of testing the hypothesis is to conduct a regression analysis of the value of the misfit, namely the residual value that is absolute between the MCS and the type of organizational culture, whether it affects the LPD's financial performance or vice versa. The results of the analysis are shown in Table 3.

\subsection{Hypothesis 1 Testing.}

Hypothesis 1 of the study suspects that a misfit between organizational culture (Clan) and MCS will negatively affect LPD's financial performance. Table 2 shows that using simple linear regression as the initial stage of the residual test shows that MCS does not affect the organizational culture of the clan. In other words, the effectiveness of MCS in the LPD is not related to organizational culture and work-oriented aspects such as family relationships, commitment, and a sense of belonging to a morally based organization.

Based on table 3 about testing hypothesis 1, the existence of a misfit organizational culture (clan) with MCS will affect the organization's financial performance is not supported in this study. In other words, the misfit that occurs is more likely to show the small suitability of the MCS with the organizational culture (clan) that occurs in the organization that cannot affect the organization's financial performance. This shows that the type of culture and clan is not sufficient to support the implementation of MCS in the LPD in an organized manner and is supported by an attitude of professionalism in carrying out work following the values of good LoC. As stated by (Cameron et al., 2006) and Kimbrough \& Componation (2015), an organization's culture can be seen from the most dominant side in the organization. The cultural relationship is determined by factors: strength, congruence, type of culture, and organizational effectiveness. Based on the MCS context, hence the clan's organizational culture is considered less supportive of the proper implementation of the MCS to have an impact on the LPD's financial performance.

\subsection{Hypothesis 2 Testing}

Hypothesis 2 suspects that a misfit between organizational culture (Adhocracy) and MCS will negatively affect the LPD's financial performance. Based on table 2, the 
results of simple linear regression as the initial stage of the residual test show that MCS does not affect the adhocracy organizational culture. In other words, the effectiveness of MCS in the LPD does not adhere to the kind of adhocracy culture that is more workoriented as entrepreneurship and innovator (product innovation).

Table 3 shows that hypothesis 2 , which wants to prove the existence of a misfit of organizational culture (adhocracy) with MCS, will affect the financial performance of the LPD, is not supported in this study. In other words, the misfit that occurs is more likely to indicate the small suitability of the MCS with organizational culture (adhocracy) that occurs in the LPD cannot affect the LPD's financial performance. This shows that in the sample organizations, the adhocracy culture type cannot support MCS implementation in organizations such as the LPD. Adhocracy cultural orientation that expects workers as product innovators can pressure workers to work optimally to support organizational performance.

Cameron et al. (2006) and Kimbrough \& Componation (2015) state that certain types of culture, such as adhocracy can be seen as the type that dominates a particular organization. However, based on the research results, it is evident that based on the MCS context, the adhocracy organizational culture does not support the implementation of MCS to produce organizational financial performance. This is different from Zhao et al.'s (2018) research, which found that organizational culture is only related to the organization's innovation. However, it also cannot prove its impact on organizational values and performance.

\subsection{Hypothesis 3 Testing}

Hypothesis 3 suspects that a misfit between the type of organizational culture (Hierarchy) and MCS will negatively affect the organization's financial performance. Based on table 2, the results of simple linear regression as the initial stage of the residual test show that MCS does not affect hierarchical organizational culture. In other words, the effectiveness of MCS in LPD tends to be in organizations with a hierarchical type of culture that is more organized and structured based on the details of work in carrying out its duties. 
Table 3 shows that hypothesis 3 , which tests the existence of a misfit of organizational culture (hierarchy) with MCS, will affect the financial performance of the LPDs supported in this study. In other words, the misfit that occurs is more likely to indicate the conformity of the MCS with the organizational culture (hierarchy) that occurs in the organization so that it affects the LPD's financial performance. This proves that in the LPD, the hierarchical culture type follows the implementation of MCS in the organization as a system based on structured and routine information to realize organizational goals (Simons, 1994). The hierarchical culture orientation conditions the organization on stability, efficiency, control, and smooth operation. This shows that the LPD tends to be in this type of culture so that it is compatible with the MCS, so it can affect the LPD's financial performance.

Cameron et al. (2006) and Kimbrough \& Componation (2015) suggest that certain types of culture, such as hierarchy are seen as the type that dominates a particular organization. The research results prove that based on the MCS context, the hierarchical organizational culture supports the implementation of the MCS to produce organizational financial performance. In contrast to the research (Zhao et al., 2018) found that organizational culture is only related to the organization's innovation. However, it also cannot prove its impact on organizational values and performance.

\subsection{Hypothesis 4 Testing}

Hypothesis 4 suspects that a misfit between the type of organizational culture (Market) and MCS will negatively affect the LPD's financial performance. Based on table 2, the results of simple linear regression as the initial stage of the residual test indicate that MCS does not affect market organizational culture. In other words, the effectiveness of MCS in organizations that are in organizations with a market culture type that is more results-oriented and completes work does not support or match the implementation of MCS in the LPD.

Based on table 3, shows that hypothesis 4, which tests the existence of a misfit of organizational culture (market) with MCS, is not proven to affect the financial performance of LPDs in this study. In other words, the misfit that occurs is more likely 
to indicate a mismatch between the MCS and the organizational culture (market) that occurs in the LPD, thus affecting the LPD's financial performance. Based on market culture orientation which tends to emphasize task completion and target achievement through production orientation and winning markets and competition, it can be concluded that workers are under conditions of high work pressure so that when organizations lack information as a basis for implementing MCS, market culture becomes a matter. which is very detrimental to the organization. In this case, the suitability of the MCS and market culture cannot contribute to the achievement of LPD financial performance.

As in the previous discussion, Cameron et al. (2006) and Kimbrough \& Componation (2015) suggest that certain cultural types such as mock-ups are seen as the type that dominates a particular organization. The results of this research prove that based on the context of the MCS, the market organizational culture does not support the implementation of the MCS to produce organizational financial performance. This is in line with Zhao et al. (2018) found that organizational culture cannot prove its impact on organizational values and performance.

This research contributes to the topic of MCS in LPD that has never been done in previous studies. Based on the results of hypothesis testing, it proves that empirically LPD management still adheres to an appropriate hierarchical culture (small misfit value) with MCS both on belief, boundary, diagnostic and interactive control to influence LPD financial performance. All LPD operations are guided by a culture that is formal and structured. All forms of work are carried out based on procedures, coordination so that the organization will become more stable, predictive, and efficient through formal rules and policies made for LPD operations in providing services to customers, namely the local customary community (krama) and performance accountability to BPD and local governments. The main thing that clearly shows the identity of the LPD is its arrangement in the customary village awig-awig, which applies normatively as the basis on which it is based. All good and bad activities of the LPD are related to customary sanctions and decisions of customary village manners. 
Nonetheless, the findings in the LPD scope are in line with Chenhall (2003) and Fauzi et al. (2011), who prove that culture in general plays a role in the operation of MSS in an effective way to influence individuals in culture to respond in different ways to its implementation. Culture as a contingent factor with MCS affects the LPD's financial performance. This confirms the contingency theory that the contingency factor of organizational culture and MCS is a management accounting system that has become the identity of the LPD as an organization in society in Bali as the specialty of culturebased microfinance institutions. There are empirical findings that the LPD's financial performance is highly dependent on the suitability of LPD contextual factors such as organizational culture and the MCS.

Meanwhile, the existence of the LPD management is hierarchical as a human resource owned by the LPD. LPD operations are primarily determined by the implementation of the duties and responsibilities of the LPD administrators who are trusted and selected by the adat village krama with the supervision of the customary bendesa (customary head in the village) to manage (collect and channel) the finances of the traditional village krama. These duties and responsibilities are based on customary and cultural values, and the boundaries made within the scope of customary villages with all the rules, financial accountability as a form of LPD performance, and the interaction between management and customary village manners in the process of transparency and operational accountability of the LPD. All of which depends on the ability of the LPD to use the resources. This confirms the resource dependence theory in the context of MCS as an accounting system that obtains and uses human resources effectively and efficiently to achieve LPD goals that promote and depend on the availability of information (information resources) to assist the duties of LPD administrators. This also shows the importance of LPD's resources, namely human resources, planning, monitoring, performance measurement, and mechanisms in an integrated manner as LPD strategic and operational control. This description is increasingly attached to the role of levers, namely beliefs (values), boundary (rules), diagnostic (performance), and interactive (communication) represented in hierarchical 
culture as factors that can support the implementation of MCS to improve LPD financial performance.

The explanation above illustrates that the LPD practice in Buleleng Regency, which aims to strengthen the resilience of Pakraman village in preserving and developing the noble values of Balinese customs and culture, is not easy to carry out activities other than what has been described in the LPD standard guidelines in a professional and structured manner. The Village Credit Institution is a village-owned financial enterprise that carries out business activities in the village environment and village residents. This provision indicates that the Village Credit Institution is a form of economic institution, which the Regional Regulation is recognized and confirmed in legal status as a form of financial enterprise, with a special nature, because it only carries out business activities in the village area. This is what proves that organizational culture values following the research results tend to be oriented towards institutional hierarchies. The important thing here is whether the LPD organizational culture, with its uniqueness as a microfinance institution based on customs and culture, can withstand changes in unpredictable external factors such as the Covid-19 pandemic will be able to maintain the LPD's financial performance? The answer that can be put forward, in this case, is that the strength of the LPD hierarchical culture according to the results of this study shows that the LPD management appointed based on the decision of communal customary krama deliberations will take joint policy steps with the traditional village krama to maintain the existence of the LPD.

\section{Conclusion, Implication, Limitation, and Suggestions}

\subsection{Conclusion}

This study aims to analyze the effect of misfit MCS and LPD culture on LPD financial performance. The results show that only a hierarchical culture applies and conforms to MSS practices that will affect the LPD's financial performance. This study indicates that the strengthening of internal organizational factors / LPD plays a significant role in providing direction for all individuals in the organization. This will support LPD operations, especially the LPD's financial performance. 


\subsection{Implication and Limitation}

The results of this study provide theoretical implications that the implementation of an accounting system (in this case, MCS) in a contingency approach will fit with contingent factors, namely organizational culture (hierarchical), to impact LPD financial performance. Practical implications show that LPD performance is strongly influenced by organizational cultural orientation and plays a significant role in individual values and behavior through the implementation of MCS in LPDs to affect the LPD's financial performance.

\subsection{Limitations}

Some limitations in this study need to be pointed out so that the interpretation of the research results is carried out carefully by considering all the existing limitations. Also, the limitations of the research are useful for the development of similar research in the future. The limitations in this study are as follows: firstly, the measurement of organizational culture has not been fully modified according to the existence of LPD based on customs and culture. However, the comprehensiveness of the measurement has represented an organizational cultural orientation such as the LPD compared to the Tri Hita Karana culture, which was more widely used in previous studies. Secondly, LPD performance measurement has not been expanded to reach non-financial LPDs. Further, the LPD sample is only limited to the scope of Buleleng Regency. Finally, the sample uses nonprobability sampling, so it cannot generalize the population.

\subsection{Suggestion}

For further research, it is expected to improve the limitations of this study by developing a more comprehensive measurement of the LPD culture, especially the LPD aspects or values, in more depth. Future study may expand the LPD sample within the scope of Bali Province as the specialty of the LPD as a traditional village microfinance institution and expansion of LPD non-financial performance measurement. Finally, the use of the momentum of the Covid-19 pandemic to test the resilience of LPD performance as a result of relaxation and credit restructuring for affected debtors, even 
though LPD is not under the regulation of the Financial Services Authority (POJK), but the POJK stimulus has an impact on the credit policy by the LPD.

\section{Reference}

Adiputra, I. M. P., Gani, L., Rossieta, H., and Hermawan, A. A. (2019). Pengaruh Misfit Ketidakpastian Bisnis yang Dipersepsikan dengan Levers of Control Terhadap Kinerja Perusahaan. Assets: Jurnal Akuntansi Dan Pendidikan, 8(2), 117. https://doi.org/10.25273/jap.v8i2.4435

Agustina, I. D. G., Bagus, I., Purbawangsa, A., Gede, L., and Artini, S. (2017). Evaluasi Tingkat Kesehatan Lembaga Perkreditan Desa (Lpd) Di Kabupaten Klungkung. Buletin Studi Ekonomi, 113-121.

Riyanto, LS., B. (2001). Alternative Approach to Examining a Contingency Model in Accounting Research: A Comparison. Jurnal Riset Akuntansi, Manajemen Ekonomi., $1(1)$.

Bali Provincial Regulation No.4 of 2012 concerning the Second Amendment to the Bali Provincial Regulation concerning Village Credit Institutions Regarding LPD Health Assessment Procedures.

Bedford, D. S. (2015). Management control systems across different modes of innovation: Implications for firm performance. Management Accounting Research, 28, 12-30. https://doi.org/10.1016/j.mar.2015.04.003

Bisbe, J., Batista-Foguet, J. M., and Chenhall, R. (2007). Defining management accounting constructs: A methodological note on the risks of conceptual misspecification. Accounting, Organizations and Society, 32(7-8), 789-820. https://doi.org/10.1016/j.aos.2006.09.010

Cadez, S., and Guilding, C. (2008). An exploratory investigation of an integrated contingency model of strategic management accounting. Accounting, Organizations and Society, 33(7-8), 836-863. https://doi.org/10.1016/j.aos.2008.01.003

Cameron, K. S., and Quinn, R. E. (1999). Diagnosing and changing organizational culture: Based on the competing values framework. Reading, MA: Addison-Wesley.

Cameron, K.S., De Graff, J., Quinn, R.E., and Thakor, A. (2006). Competing Values Leadership: Creating Value in Organisations. Edward Elgar, Cheltenham.

Chenhall, R. H. (2003). Management control systems design within its organizational context: findings from contingency-based research and directions for the future. Accounting, Organizations and Society, 28, 127-168.

Chet Miller, C., Washburn, N. T., and Glick, W. H. (2013). The myth of firm performance. Organization Science, 24(3), 948-964. https://doi.org/10.1287/orsc.1120.0762 
Drazin, R., and Van De Ven, A. H. (1985). Alternative Forms of Fit in Contingency Theory. In Quarterly (Vol. 30, Issue 4). https://www.jstor.org/stable/2392695?seq=1\&cid=pdfreference\#references_tab_contents

Duncan, K.R, and Moores, K. (1989). Residual analysis: A better methodology for contingent studies in management accounting. Journal of Management Accounting Research, 1, 89-103.

Fauzi, H., Hussain, M. M., and Mahoney, L. (2011). Management Control Systems and Contextual Variables in the Hospitality Industry. Asia-Pacific Management Accounting Journal, 6(2), 63-83.

Fisher, J. (1998). Contingency theory, management control systems and firm outcome: past results and future directions. Behavioral Research in Accounting, 10, 47-64.

Gani, L., and Jermias, J. (2012). The Effects of Strategy-Management Control System Misfits on Firm Performance. Accounting Perspectives. https://doi.org/10.1111/j.19113838.2012.00038.x

Gerdin, J., and Greve, J. (2008). The appropriateness of statistical methods for testing contingency hypotheses in management accounting research. Accounting, Organizations and Society, 33(7-8), 995-1009. https://doi.org/10.1016/j.aos.2007.07.003

Ghozali, I. (2012). Aplikasi Analisis Multivariate dengan Program IBM SPSS. Yogyakarta: Universitas Diponegoro.

Gochhayat, J., Giri, V. N., and Suar, D. (2017). Influence of Organizational Culture on Organizational Effectiveness: The Mediating Role of Organizational Communication. Global Business Review, 18(3), 691-702. https://doi.org/10.1177/0972150917692185

Governor's Decree Number 972 of 1984 concerning the Establishment of Village Credit Institutions in the Province of Bali

Governor Regulation No. 44 of 2017 as the Implementation Regulation of Bali Provincial Regulation No. 3 of 2017 concerning LPD with the methods used are Capital, Asset, Management, Earning, Liquidity (CAMEL).

Ittner, C. D., Larcker, D. F., and Randall, T. (2003). Performance implications of strategic performance measurement in financial services firms. 28, 715-741. https://doi.org/10.1016/S0361-3682(03)00033-3

Jermias, J., and Gani, L. (2004). Integrating business strategy, organizational configurations, and management accounting systems with business unit effectiveness: A fitness landscape approach. Management Accounting Research, 15(2), 179-200. https://doi.org/10.1016/j.mar.2004.03.002 
Jermias, J., and Gani, L. (2005). Ownership structure, contingent-fit, and business-unit performance: A research model and empirical evidence B. The International Journal of Accounting, 40, 65-85. https://doi.org/10.1016/j.intacc.2005.01.004

Kaplan, S., and David, N. (1996). The Balanced Scorecard: Translating Strategy into Action. Boston, MA: Harvard Business School Press.

Kimbrough, R. L., and Componation, P. J. (2015). The relationship between organizational culture and enterprise risk management. EMJ - Engineering Management Journal, 21(2), 18-26. https://doi.org/10.1080/10429247.2009.11431803

Kruis, A.-M., Speklé, R. F., \& Widener, S. K. (2015). The Levers of Control Framework: An exploratory analysis of balance.

Kurniasari, T. W. (2007). Lembaga Perkreditan Desa Dalam Perspektif Hukum; Sebuah Lembaga Keuangan Adat Hindu Penggerak Usaha Sektor Informal Di Bali. Jurnal Masyarakat Dan Budaya, 9(1), 53-78.

Langfield-Smith, K. (1997). Management Control Systems and Strategy: A critical review, Accounting, Organizations and Society, 22 (2), 207-232. https://doi.org/10.1016/S0361-3682(95)00040-2

LP-LPD Buleleng Optimalkan Pembinaan SDM untuk Majukan LPD. (2019). Retrieved from http://bisnisbali.com/lp-lpd-buleleng-optimalkan-pembinaan-sdm-untuk-majukan-lpd/

Trisnawati, N.L.E., Pasek, G.W., and Kartika, R.D. (2019). Nilai catur pur usa artha dan struktur modal sebagai kunci maksimalisasi kinerja keuangan di LPDD Kabupaten Buleleng. SINTESA, Prosiding, 497-504.

Martyn, P., Sweeney, B., and Curtis, E. (n.d.). Strategy and control: 25 years of empirical use of Simons' Levers of Control framework. https://doi.org/10.1108/JAOC-03-2015-0027

Mundy, J. (2010). Creating dynamic tensions through a balanced use of management control systems. Accounting, Organizations and Society, 35(5), 499-523. https://doi.org/10.1016/j.aos.2009.10.005

Otley, D. (2016). The contingency theory of management accounting and control: 1980-2014. Management Accounting Research, 31, 45-62. https://doi.org/10.1016/j.mar.2016.02.001

Otley, D. T. (1980). The contingency theory of management accounting: Achievement and prognosis. Accounting, Organizations and Society, 5(4), 413-428. https://doi.org/10.1016/0361-3682(80)90040-9

Pancadana, D. ., and Parwata, A. A. G. O. (n.d.). Catur purusa artha sebagai dasar kegiatan usaha lembaga perkreditan desa (lpd) di desa pakraman kikian. 1-5.

Pešalj, B., Pavlov, A., and Micheli, P. (2018). The use of management control and performance 
measurement systems in SMEs: A levers of control perspective. International Journal of Operations and Production Management, 38(11), 2169-2191. https://doi.org/10.1108/IJOPM-09-2016-0565

Pfeffer, J., and Salancik, G. R. (1978). The external control of organizations: A resource dependency perspective. New York: Harper \& Row.

Regional Regulation Number 3 of 2017 concerning Village Credit Institutions

Said, A. A., HassabElnaby, H. R., and Wier, B. (2003). An Empirical Investigation of the Performance Consequences of Non-financial Measures. Journal of Management Accounting Research, 15(1), 193-223. https://doi.org/10.2308/jmar.2003.15.1.193

Simons, R. (1994). How New Top Managers Use Control Systems as Levers of Strategic Renewal. Strategic Management Journal, 15(3), 169-189.

Simons, R. (2000). Performance measurement and control systems for implementing strategy: text and cases. Upper Saddle River NJ) by Prentice-Hall.

Simons, R. (2014). Performance measurement and control systems for implementing strategy. England: Pearson.

Simons, R. (1995). Levers of Control: How Managers Use Innovative Control Systems to Drive Strategic Renewal. Harvard Business School Press, Boston.

Simons, R. (1987). Accounting control systems and business strategy: An empirical analysis. Accounting, Organizations and Society, 12, 357-374.

Simons, R. (1994). How new top managers use control systems as levers of strategic renewal. Strategic Management Journal, 15, 169-189.

Speklé, R. F. (2001). Explaining management control structure variety: A transaction cost economics perspective. Accounting, Organizations and Society, 26(4-5), 419-441. https://doi.org/10.1016/S0361-3682(00)00041-6

Suartana, I.W., and Ariyanto, D. (2012). Analisis kinerja internal, balance scorecard dan pengembangan keuangan mikro berkelanjutan (studi pada LPD di Provinsi Bali). Jurnal Akuntansi \& Auditing, 9(1), 56-69.

Subramaniam, N., Collier, P., Phang, M., and Burke, G. (2011). The effects of perceived business uncertainty, external consultants, and risk management on organisational outcomes. Journal of Accounting and Organizational Change, 7(2), 132-157. https://doi.org/10.1108/18325911111139671

Sujana, I.K., Suardikha, I.M.S., and Dwirandra, A.A.N.B. (2018). Pertumbuhan Laba Pada Lembaga Lembaga Perkreditan Desa. Jurnal Ilmiah Akuntansi dan Bisnis, 13 (2), 185 196. 
Suryanata, I.G.N.P. (2019). Sinergitas Lembaga Perkreditan Desa Dalam Membangun Perekonomian Masyarakat. Jurnal Manajemen Bisnis, 16 (1), 206-229.

Tuomela, T. S. (2005). The interplay of different levers of control: A case study of introducing a new performance measurement system. Management Accounting Research, 16(3 SPEC. ISS.), 293-320. https://doi.org/10.1016/j.mar.2005.06.003

Widener, S. K. (2007). An empirical analysis of the levers of control framework. Organizations and Society, 32, 757-788. https://doi.org/10.1016/j.aos.2007.01.001

Zhao, H., Teng, H., and Wu, Q. (2018). The effect of corporate culture on firm performance: Evidence from China. China Journal of Accounting Research, 11(1), 1-19. https://doi.org/10.1016/j.cjar.2018.01.003 
The Indonesian Journal of Accounting Research - Jan, Vol. 24, No.1, 2021

intentionally blank 